\title{
Citation Analysis of the Most Influential Publications in Travel Medicine
}

\author{
Gerard T. Flaherty ${ }^{1,2^{*}}$, Darragh P. Browne ${ }^{1}$ \\ ${ }^{1}$ School of Medicine, National University of Ireland Galway, Galway, Ireland \\ ${ }^{2}$ School of Medicine, International Medical University, Kuala Lumpur, Malaysia
}

Corresponding Author: Gerard T. Flaherty, MD, Professor; School of Medicine, National University of Ireland Galway, Galway, Ireland; School of Medicine, International Medical University, Kuala Lumpur, Malaysia. Tel.: +35391495469; Fax:+35391494540; Email: gerard.flaherty@nuigalway.ie

Received November 2, 2016; Accepted November 9, 2016; Online Published December 5, 2016

\begin{abstract}
Introduction: Citation analysis reflects the extent to which published work has been recognized in the scientific community. The purpose of this study was to characterize the most cited publications in travel medicine.

Methods: Travel medicine articles indexed on Scopus which had been published in the English language through 2016 were retrieved independently by two researchers using various search terms. Eligible articles with at least 50 citations were ranked according to citation count. Additional information was recorded, including authorship, year of publication, journal, journal impact factor, source country, institution of origin, category of article, level of evidence and principal article theme.

Results: Among the 174 most cited articles, the greatest number of citations recorded was 1217 for an original research article published in 2013. The most productive decade for most cited articles was 2000-2010. Of the articles, 122 were original research, 47 were reviews, and 5 were of other article types. The top-ranked author published 15 articles among the most cited. The most prolific institution among the most influential papers was based in Munich, Germany. Nine broad themes emerged from the most cited publication list, with air travel (29), malaria (26), post-travel assessment (16), travelers' diarrhea (14), and high altitude illness (13) being the most prominent subjects.

Conclusion: Travel medicine research has proliferated since the founding of the discipline in the 1970s. This first citation analysis of travel medicine research provides an historical perspective and highlights sources of greatest influence on the travel medicine community.

Keywords: Medicine, Travel, Citation, Bibliometric analysis, Evidence-based medicine
\end{abstract}

Citation: Flaherty GT, Browne DP. Citation analysis of the most influential publications in travel medicine. Int J Travel Med Glob Health 2016;4(4):122-131. doi:10.21859/ijtmgh-040407.

\begin{abstract}
Introduction
Since its origins in the early 1980s, travel medicine has matured into a multidisciplinary specialism which serves the health needs of growing numbers of international travelers. The body of knowledge of the International Society of Travel Medicine has become increasingly complex, and specialty postgraduate training pathways in this discipline have started to emerge. ${ }^{1}$ Travel medicine is also being incorporated into undergraduate medical curricula in the British Isles. ${ }^{2}$ Multiple international conferences on travel medicine, including the Conference of the International Society of Travel Medicine and the Northern European Conference on Travel Medicine, enable researchers to showcase their original works in the field. The Journal of Travel Medicine came into existence as the first specialist travel medicine journal in 1994 and
\end{abstract}

is now ranked as 48 th of 151 peer-reviewed journals in the category of General Medicine. Travel medicine has embraced the concept of evidence-based clinical practice, and research priorities have been proposed ${ }^{3}$ which will stimulate further original studies in domains where gaps in the evidence have been identified.

Citation analysis is a bibliometric technique which calculates the number of times a published article has been cited as evidence in another publication. ${ }^{4}$ It has already been used in a variety of specialties, including plastic and reconstructive surgery, ${ }^{5}$ cardiac surgery, ${ }^{6}$ emergency medicine, ${ }^{7}$ and critical care medicine. ${ }^{8}$ Articles reporting data which is likely to influence the direction of future research in travel medicine may be expected to yield higher citation numbers. Tabulating the citation metrics of articles published in travel medicine 
should provide insights into publication trends and areas of greatest research activity in the field and inform the prediction of future research strategies. This study is the first reported citation analysis of travel medicine-related articles published in English. By analyzing the characteristics of these publications, the qualities which make a travel medicine paper important to the specialty are elucidated.

\section{Methods}

Several journal-indexing databases were explored and a university bibliometrician was consulted. Scopus was identified as the largest citation database of peer-reviewed literature. ${ }^{9}$ Articles published in English through 2016 and indexed on Scopus were retrieved between April and July 2016 using the key terms "travel medicine," "tropical medicine," "altitude medicine," "expedition medicine," "aerospace medicine," aviation medicine," "cruise ship medicine," "asylum seeker and refugee healthcare," and "migrant medicine." Additionally, all articles published in the Journal of Travel Medicine and Travel Medicine and Infectious Disease were screened by number of citations. Manual screening excluded works deemed not relevant to travel medicine. Self-cited articles were not excluded from analysis. Eligible articles with at least 50 citations were combined into a single database and ranked according to number of citations on 27 July 2016. Additional information recorded included year of publication, journal of publication, journal impact factor, country and institution of origin, category of article, and principal article theme. Authorship in any position in the publication was also tabulated. The temporal publication trend was investigated for the most cited articles. The levels of evidence (I-V) of clinical articles were determined by referring to the Oxford Centre for Evidence-Based Medicine classification system. ${ }^{10}$ Both authors independently conducted literature searches and agreed upon the final list of articles to be analyzed.

\section{Results}

The primary literature search revealed a total of 1355 articles. After non-travel medicine-related articles were excluded, the remaining articles were ranked according to number of citations received. Articles with 50 or more citations were included in the analysis (Table 1). All of the articles were published in the English language. Of the 174 articles, the greatest number of citations recorded was 1217

Table 1. Citation Metrics of Most Influential Papers in Travel Medicine

\section{Rank Article}

1 Bhatt S, Gething PW, Brady OJ, et al. The global distribution and burden of dengue. Nature 2013; 496:504-507.

Freedman DO, Weld LH, Kozarsky PE, et al. Spectrum of disease and relation to place of exposure among ill returned travelers. N Engl J Med 2006; 354:119-130.

Hufnagel L, Brockmann D, Geisel T. Forecast and control of epidemics in a globalized world. Proc Natl Acad Sci USA 2004; 101:1512415129.

4 Lapostolle F, Surget V, Borron SW, et al. Severe pulmonary embolism associated with air travel. N Engl J Med 2001; 345:779-783. Wongsrichanalai C, Barcus MJ, Muth S, et al. A review of malaria diagnostic tools: microscopy and rapid diagnostic test (RDT). Am J Trop Med Hyg 2007; 77:119-127.

Kain KC, Harrington MA, Tennyson S, Keystone JS. Imported malaria: Prospective analysis of problems in diagnosis and management. Clin Infect Dis 1998; 27:142-149

Connell J. Medical tourism: Sea, sun, sand and...Surgery Tour Manag 2006; 27:1093-1100.

8 Nosten F, White NJ. Artemisinin-based combination treatment of falciparum malaria. Am J Trop Med Hyg 2007; 77:181-192.

Hilton E, Kolakowski P, Singer C, Smith M. Efficacy of Lactobacillus GG as a diarrheal preventive in travelers. J Travel Med 1997; 4:41-43.

Mangili A, Gendreau MA. Transmission of infectious diseases during commercial air travel. Lancet 2005; 365:989-996.

Caumes E, Carrière J, Guermonprez G, et al. Dermatoses associated with travel to tropical countries: A prospective study of the diagnosis and management of 269 patients presenting to a tropical disease unit. Clin Infect Dis 1995; 20:542-548.

Van Herck K, Castelli F, Zuckerman J, et al. Knowledge, attitudes and practices in travel-related infectious diseases: The European airport survey. J Travel Med 2004; 11:3-8.

Wilson ME, Weld LH, Boggild A, et al. Fever in returned travelers: Results from the Geosentinel surveillance network. Clin Infect Dis 2007; 44:1560-1568.

14 Baker SP, Whitfield RA, O'Neill B. Geographic variations in mortality from motor vehicle crashes. N Engl J Med 1987; 316:1384-1387.

16 San Martín JL, Brathwaite O, Zambrano B, et al. The epidemiology of dengue in the Americas over the last three decades: A worrisome reality. Am J Trop Med Hyg 2010; 82:128-135.

17 Khan K, Arino J, Hu W, et al. Spread of a novel influenza a (H1N1) virus via global airline transportation. N Engl J Med 2009; 361:212-214.

18* McFarland LV. Meta-analysis of probiotics for the prevention of traveler's diarrhea. Travel Med Infect Dis 2007; 5:97-105.

19 Dick GWA. Zika virus (i). Isolations and serological specificity. Trans R Soc Trop Med Hyg 1952; 46:509-520.

Bacaner N, Stauffer B, Boulware DR, et al. Travel medicine considerations for North American immigrants visiting friends and relatives. JAMA 2004; 291:2856-2864.

21* Lalloo DG, Shingadia D, Pasvol G, et al. UK malaria treatment guidelines. J Infect 2007; 54:111-121.

22 Hamer DH, Connor BA. Travel health knowledge, attitudes and practices among United States travelers. J Travel Med 2004; 11:23-26.

23 Cho K. Chronic 'jet lag' produces temporal lobe atrophy and spatial cognitive deficits. Nat Neurosci 2001; 4:567-568. Hill DR, Baird JK, Parise ME, et al. Primaquine: Report from CDC expert meeting on malaria chemoprophylaxis I. Am J Trop Med Hyg 2006; 75:402-415.

Coker R. Managing passengers with respiratory disease planning air travel: British Thoracic Society recommendations: British Thoracic 
Kozicki M, Steffen R, Schär M. 'Boil it cook it, peel it or forget it': Does this rule prevent travellers' diarrhoea? Int J Epidemiol 1985; 14:169-172.

121.

31* Beare NAV, Taylor TE, Harding SP, et al. Malarial retinopathy: A newly established diagnostic sign in severe malaria. Am J Trop Med Hyg 2006; 75:790-797.

León-Velarde F, Maggiorini M, Reeves JT, et al. Consensus statement on chronic and subacute high altitude diseases. High Alt Med Biol 2005; 6:147-157.

33 Luks AM, McIntosh SE, Grissom CK, et al. Wilderness Medical Society consensus guidelines for the prevention and treatment of acute altitude illness. Wilderness Environ Med 2010; 21:146-155.

Gubler DJ, Trent DW. Emergence of epidemic dengue/dengue hemorrhagic fever as a public health problem in the Americas. Infect Agents Dis 1993; 2:383-393.

35 Ryan ET, Kain KC. Health advice and immunizations for travelers. N Engl J Med 2000; 342:1716-1725.

43 Sarvesvaran R. Sudden natural deaths associated with commercial air travel. Med Sci Law 1986; 26:35-38.

45 Balmaseda A, Hammond SN, Pérez L, et al. Serotype-specific differences in clinical manifestations of dengue. Am J Trop Med Hyg 2006; 74:449-456.

46* Jensenius M, Fournier PE, Vene S, et al. African tick bite fever in travelers to rural sub-equatorial Africa. Clin Infect Dis 2003; 36:14111417. 468.

49 Marx A, Pewsner D, Egger M, et al. Meta-analysis: Accuracy of rapid tests for malaria in travelers returning from endemic areas. Ann Intern Med 2005; 142:836-846.

50* Arendt J, Deacon S. Treatment of circadian rhythm disorders - melatonin. Chronobiol Int 1997; 14:185-204.

Steffen R. 3. Travel medicine-prevention based on epidemiological data. Trans R Soc Trop Med Hyg 1991; 85:156-162.

Gendreau MA, Dejohn C. Responding to medical events during commercial airline flights. N Engl J Med 2002; 346:1067-1073.

Hughes RJ, Hopkins RJ, Hill S, et al. Frequency of venous thromboembolism in low to moderate risk long distance air travellers: The New

53 Zealand air traveller's thrombosis (NZATT) study. Lancet 2003; 362:2039-2044.

54 Schwartz GB. Medical aspects of transportation aboard commercial aircraft. AMA commission on emergency medical services. JAMA 1982; 247:1007-1011.

55* Taylor DN, Bourgeois AL, Ericsson CD, et al. A randomized, double-blind, multicenter study of rifaximin compared with placebo and with ciprofloxacin in the treatment of travelers' diarrhea. Am J Trop Med Hyg 2006; 74:1060-1066.

56 Cummins RO, Schubach JA. Frequency and types of medical emergencies among commercial air travelers. JAMA 1989; 261:1295-1299.

57 Berglund B. High-altitude training: Aspects of haematological adaptation. Sports Med 1992; 14:289-303.

58* Ansart S, Perez L, Vergely O, et al. Illnesses in travelers returning from the tropics: A prospective study of 622 patients. J Travel Med 2005 ; 12:312-318.

59 Memish ZA, Balkhy HH. Brucellosis and international travel. J Travel Med 2004; 11:49-55.

60 Shlim DR, Solomon T. Japanese encephalitis vaccine for travelers: Exploring the limits of risk. Clin Infect Dis 2002; 35:183-188.

61* Cho K, Ennaceur A, Cole JC, Suh CK. Chronic jet lag produces cognitive deficits. J Neurosci 2000; 20.

62 Spitzer RL, Terman M, Williams JBW, et al. Jet lag: Clinical features, validation of a new syndrome-specific scale, and lack of response to melatonin in a randomized, double-blind trial. Am J Psychiatry 1999; 156:1392-1396.

63 O'Brien K, Friedberg W, Sauer HH, Smart DF. Atmospheric cosmic rays and solar energetic particles at aircraft altitudes. Environ Int 1997; 22 Suppl1: S9-44.

64 Freedman DO, Kozarsky PE, Weld LH, et al. Geosentinel: The global emerging infections sentinel network of the International Society of 64 Travel Medicine. J Travel Med 1999; 6:94-98.

65* Lewis HC, Wichmann O, Duizer E. Transmission routes and risk factors for autochthonous hepatitis E virus infection in Europe: A systematic review. Epidemiol Infect 2010; 138:145-166.

66 Riddle MS, Sanders JW, Putnam SD, Tribble DR. Incidence, etiology, and impact of diarrhea among long-term travelers (US military and similar populations): A systematic review. Am J Trop Med Hyg 2006; 74:891-900.

67 Balkhy $\mathrm{HH}$, Memish ZA, Bafaqeer S, Almunee

68 López-Vélez R, Huerga H, Turrientes MC. Infectious diseases in immigrants from the perspective of a tropical medicine referral unit. Am J 
Buskirk ER, Kollias J, Akers RF, et al. Maximal performance at altitude and on return from altitude in conditioned runners. J Appl Physiol $1967 ; 23: 259-266$.

71 Singh I, Kapila CC, Khanna PK, et al. High-altitude pulmonary œedema. Lancet 1965; 285:229-234.

72 Lederman ER, Weld LH, Elyazar IRF, et al. Dermatologic conditions of the ill returned traveler: An analysis from the Geosentinel 72 surveillance network. Int J Infect Dis 2008; 12:593-602.

73* Toovey S, Jamieson A, Holloway M. Travelers' knowledge, attitudes and practices on the prevention of infectious diseases: Results from a study at Johannesburg international airport. J Travel Med 2004; 11:16-22.

74 Krasney JA. A neurogenic basis for acute altitude illness. Med Sci Sports Exerc 1994; 26:195-208.

75* Silverman D, Gendreau M. Medical issues associated with commercial flights. Lancet 2009; 373:2067-2077.

Suhner A, Schlagenhauf P, Johnson R, et al. Comparative study to determine the optimal melatonin dosage form for the alleviation of jet lag. Chronobiol Int 1998; 15:655-666.

Dillard TA, Berg BW, Rajagopal KR, et al. Hypoxemia during air travel in patients with chronic obstructive pulmonary disease. Ann Intern Med 1989; 111:362-367.

Alvarez M, Rodriguez-Roche R, Bernardo L, et al. Dengue hemorrhagic fever caused by sequential dengue 1-3 virus infections over a long time interval: Havana epidemic, 2001-2002. Am J Trop Med Hyg 2006; 75:1113-1117.

79 Kelman CW, Kortt MA, Becker NG, et al. Deep vein thrombosis and air travel: Record linkage study. BMJ 2003; 327:1072-1075.

Wilhelm FH, Roth WT. Taking the laboratory to the skies: Ambulatory assessment of self- report, autonomic, and respiratory responses in flying phobia. Psychophysiology 1998; 35:596-606.

81 Kitchen AD, Chiodini PL. Malaria and blood transfusion. Vox Sang 2006; 90:77-84.

82 Van Damme P, Van Herck K. A review of the long-term protection after hepatitis A and B vaccination. Travel Med Infect Dis 2007; 5:79-84.

83* Thompson FM, Porter DW, Okitsu SL, et al. Evidence of blood stage efficacy with a virosomal malaria vaccine in a phase Ila clinical trial. PLOS ONE 2008; 3.

Libman MD, MacLean JD, Gyorkos TW. Screening for schistosomiasis, filariasis, and strongyloidiasis among expatriates returning from the tropics. Clin Infect Dis 1993; 17:353-359.

Field V, Gautret P, Schlagenhauf P, et al. Travel and migration associated infectious diseases morbidity in Europe, 2008. BMC Infect Dis $2010 ; 10$.

Alonso D, Muñoz J, Gascón J, et al. Short report: Failure of standard treatment with praziquantel in two returned travelers with Schistosoma haematobium infection. Am J Trop Med Hyg 2006; 74:342-344.

Schlagenhauf P, Steffen R, Loutan L. Migrants as a major risk group for imported malaria in European countries. J Travel Med 2003; 10:106-107.

Rogers BA, Aminzadeh Z, Hayashi Y, Paterson DL. Country-to-country transfer of patients and the risk of multi-resistant bacterial infection. Clin Infect Dis 2011; 53:49-56.

Van Herck K, Zuckerman J, Castelli F, et al. Travelers' knowledge, attitudes, and practices on prevention of infectious diseases: Results from a pilot study. J Travel Med 2003; 10:75-78.

Hahné SJM, Gray SJ, Aguilera JF, et al. W135 meningococcal disease in England and Wales associated with hajj 2000 and 2001. Lancet 2002; 359:582-583.

92 Hawkes S, Hart GJ, Johnson AM, et al. Risk behaviour and HIV prevalence in international travellers. AIDS 1994; 8:247-252.

96* Nagda NL. Low relative humidity and aircraft cabin air quality. Indoor Air 2001; 11:200-214.

97 Gong Jr H. Air travel and oxygen therapy in cardiopulmonary patients. Chest 1992; 101:1104-1113.

98* Dupont HL, Ericsson CD, Farthing MJG, et al. Expert review of the evidence base for prevention of travelers' diarrhea. J Travel Med 2009; 16:149-160.

99 Chen LH, Wilson ME, Schlagenhauf P. Prevention of malaria in long-term travelers. JAMA 2006; 296:2234-2244.

101 environmental preventive measures in travelers exiting Zimbabwe from Harare and Victoria Falls international airport. J Travel Med 2001. 8:298-303.

102 Levine BD, Friedman DB, Engfred K, et al. The effect of normoxic or hypobaric hypoxic endurance training on the hypoxic ventilatory response. Med Sci Sports Exerc 1992; 24:769-775.

Angell SY, Behrens RH. Risk assessment and disease prevention in travelers visiting friends and relatives. Infect Dis Clin North Am 2005; 19:49-65.

104* Rack J, Wichmann O, Kamara B, et al. Risk and spectrum of diseases in travelers to popular tourist destinations. J Travel Med 2005; 12:248-253

Daniels J, Oldridge N. The effects of alternate exposure to altitude and sea level on world-class middle-distance runners. Med Sci Sports

105 Exerc 1970; 2:107-112.

Hills SL, Griggs AC, Fischer M. Japanese encephalitis in travelers from non-endemic countries, 1973-2008. Am J Trop Med Hyg 2010; 82:930-936.

Adams WC, Bernauer EM, Dill DB, Bomar Jr JB. Effects of equivalent sea level and altitude training on VO2(max) and running performance. J Appl Physiol 1975; 39:262-266.

108* Toovey S. Mefloquine neurotoxicity: A literature review. Travel Med Infect Dis 2009; 7:2-6.

109 Spira AM. Preparing the traveller. Lancet 2003; 361:1368-1381.

110 Dowdall N. 'Is there a doctor on the aircraft?' Top 10 in-flight medical emergencies. BMJ 2000; 321:1336-1337. 
111 Wiederhold BK, Jang DP, Gevirtz RG, et al. The treatment of fear of flying: A controlled study of imaginal and virtual reality graded exposure therapy. IEEE Trans Inf Technol Biomed 2002; 6:218-223.

112* Grandière-Pérez L, Ansart S, Paris L, et al. Efficacy of praziquantel during the incubation and invasive phase of Schistosoma haematobium schistosomiasis in 18 travelers. Am J Trop Med Hyg 2006; 74:814-818.

113 Stienlauf S, Segal G, Sidi Y, Schwartz E. Epidemiology of travel-related hospitalization. J Travel Med 2005; 12:136-141.

114 Leder K, Newman D. Respiratory infections during air travel. Intern Med J 2005; 35:50-55.

115 Arya R, Barnes JA, Hossain U, et al. Long-haul flights and deep vein thrombosis: A significant risk only when additional factors are also present. Br J Haematol 2002; 116:653-654.

116* Ahmedzai S, Balfour-Lynn IM, Bewick T, et al. Managing passengers with stable respiratory disease planning air travel: British Thoracic

116* Society recommendations. Thorax 2011; 66.

117 Monge-Maillo B, Jiménez BC, Pérez-Molina JA, et al. Imported infectious diseases in mobile populations, Spain. Emerg Infect Dis 2009; 15:1745-1752.

118 Pollard AJ, Durmowicz A, Durrer B, et al. Children at high altitude: An international consensus statement by an ad hoc committee of the International Society for Mountain Medicine, March 12, 2001. High Alt Med Biol 2001; 2:389-401.

119 McDonald JC, MacLean JD, McDade JE. Imported rickettsial disease: Clinical and epidemiologic features. Am J Med 1988; 85:799-805. Steffen R, Castelli F, Nothdurft HD, et al. Vaccination against enterotoxigenic Escherichia coli, a cause of travelers' diarrhea. J Travel Med 2005; 12:102-107.

121 Sack RL, Lewy AJ, Hughes RJ. Use of melatonin for sleep and circadian rhythm disorders. Ann Med 1998; 30:115-121.

122* Reilly T, Waterhouse J, Edwards B. Jet lag and air travel: Implications for performance. Clin Sports Med 2005; 24:367-380. Bierman WFW, Wetsteyn JCFM, Van Gool T. Presentation and diagnosis of imported schistosomiasis: Relevance of eosinophilia, microscopy for ova, and serology. J Travel Med 2005; 12:9-13.

124 Bouchaud O, Cot M, Kony S, et al. Do African immigrants living in France have long-term malarial immunity? Am J Trop Med Hyg 2005; 72:21-25.

125 Page SJ, Meyer D. Tourist accidents: An exploratory analysis. Ann Tourism Res 1996; 23:666-690.

126* López-Vélez R, Turrientes MC, Garrón C, et al. Microsporidiosis in travelers with diarrhea from the tropics. J Travel Med 1999; 6:223-227. Phillips-Howard PA, Steffen R, Kerr L, et al. Safety of mefloquine and other antimalarial agents in the first trimester of pregnancy. J Travel Med 1998; 5:121-126.

128* Greenwood Z, Black J, Weld L, et al. Gastrointestinal infection among international travelers globally. J Travel Med 2008; 15:221-228.

129 Spira AM. Assessment of travellers who return home ill. Lancet 2003; 361:1459-1469.

130 Robinson P, Jenney AW, Tachado M, et al. Imported malaria treated in Melbourne, Australia: Epidemiology and clinical features in 246

130 patients. J Travel Med 2001; 8:76-81.

131 Schwartz JS, Bencowitz HZ, Moser KM. Air travel hypoxemia with chronic obstructive pulmonary disease. Ann Intern Med 1984; 100:473477.

132 Beighton PH, Richards PR. Cardiovascular disease in air travellers. Br Heart J 1968; 30:367-372.

133* Chen LH, Wilson ME, Davis X, et al. Illness in long-term travelers visiting Geosentinel clinics. Emerg Infect Dis 2009; 15:1773-1782.

134 Lipner EM, Law MA, Barnett E, et al. Filariasis in travelers presenting to the Geosentinel surveillance network. PLoS Negl Trop Dis 2007 ; 1.

135 Hochedez P, Caumes E. Hookworm-related cutaneous larva migrans. J Travel Med 2007; 14:326-333.

136 Hall KA, Newton PN, Green MD, et al. Characterization of counterfeit artesunate antimalarial tablets from southeast Asia. Am J Trop Med Hyg 2006; 75:804-811.

137 Rendi-Wagner P. Risk and prevention of tick-borne encephalitis in travelers. J Travel Med 2004; 11:307-312.

138 Grobusch MP, Mühlberger N, Jelinek T, et al. Imported schistosomiasis in Europe: Sentinel surveillance data from TropNetEurop. J Travel Med 2003; 10:164-169.

139 Corachan M. Schistosomiasis and international travel. Clin Infect Dis 2002; 35:446-450.

140 D'Acremont V, Landry P, Mueller I, et al. Clinical and laboratory predictors of imported malaria in an outpatient setting: An aid to medical decision making in returning travelers with fever. Am J Trop Med Hyg 2002; 66:481-486.

141 Ericsson CD, DuPont HL, Mathewson JJ. Single dose ofloxacin plus loperamide compared with single dose or three days of ofloxacin in the treatment of traveler's diarrhea. J Travel Med 1997; 4:3-7.

142 Schoene RB, Roach RC, Hackett PH, et al. Operation Everest II: Ventilatory adaptation during gradual decompression to extreme altitude. Med Sci Sports Exerc 1990; 22:804-810.

143 Manzardo C, Treviño B, Gómez i Prat J, et al. Communicable diseases in the immigrant population attended to in a tropical medicine unit: epidemiological aspects and public health issues. Travel Med Infect Dis 2008; 6:4-11.

144* Lau C, Smythe L, Weinstein P. Leptospirosis: An emerging disease in travellers. Travel Med Infect Dis 2010; 8:33-39.

145 Lon CT, Tsuyuoka R, Phanouvong S, et al. Counterfeit and substandard antimalarial drugs in Cambodia. Trans R Soc Trop Med Hyg 2006; 100:1019-1024.

146 Zuckerman JN, Steffen R. Risks of hepatitis B in travelers as compared to immunization status. J Travel Med 2000; 7:170-174.

147 Bruni M, Steffen R. Impact of travel-related health impairments. J Travel Med 1997; 4:61-64.

148* Nicolls DJ, Weld LH, Schwartz E, et al. Characteristics of schistosomiasis in travelers reported to the Geosentinel surveillance network 1997-2008. Am J Trop Med Hyg 2008; 79:729-734.

149 Wilber RL. Application of altitude/hypoxic training by elite athletes. Med Sci Sports Exerc 2007; 39:1610-1624.

150 Jelinek T, Grobusch MP, Nothdurft HD. Use of dipstick tests for the rapid diagnosis of malaria in nonimmune travelers. J Travel Med 2000; 150 7:175-179.

151 Speizer C, Rennie lii CJ, Breton H. Prevalence of in-flight medical emergencies on commercial airlines. Ann Emerg Med 1989; 18:26-29.

152* Askling HH, Bruneel F, Burchard G, et al. Management of imported malaria in Europe. Malar J 2012; 11.

153 Peirano G, Laupland KB, Gregson DB, Pitout JDD. Colonization of returning travelers with ctx-m-producing Escherichia coli. J Travel Med $2011 ; 18: 299-303$.

154 Boggild AK, Castelli F, Gautret P, et al. Vaccine preventable diseases in returned international travelers: Results from the Geosentinel surveillance network. Vaccine 2010; 28:7389-7395.

155 Steffen R, Amitirigala I, Mutsch M. Health risks among travelers - need for regular updates. J Travel Med 2008; 15:145-146. 


\section{Table 1. Continued.}

56 Jones CA, Keith LG. Medical tourism and reproductive outsourcing: The dawning of a new paradigm for healthcare. Int J Fertil Womens Med 2006; 51:251-255

157 Wiederhold BK, Wiederhold MD. Three-year follow-up for virtual reality exposure for fear of flying. Cyberpsychol Behav 2003; 6:441-445.

Memish ZA, Venkatesh S, Ahmed QA. Travel epidemiology: The Saudi perspective. Int J Antimicrob Agents 2003; $21: 96-101$.

159 MacPherson DW, Guérillot F, Streiner DL, et al. Death and dying abroad: The Canadian experience. J Travel Med 2000; 7:227-233.

$160^{*}$ Sánchez-Vargas FM, Abu-El-Haija MA, Gómez-Duarte OG. Salmonella infections: An update on epidemiology, management, and prevention. Travel Med Infect Dis 2011; 9:263-277.

161

O'Brien DP, Leder K, Matchett E, et al. Illness in returned travelers and immigrants/refugees: The 6-year experience of two Australian infectious diseases units. J Travel Med 2006; 13:145-152.

162 Boggil

Lobel HO, Baker MA, Gras FA, et al. Use of malaria prevention measures by North American and European travelers to east Africa. J Travel Med 2001; 8:167-172.

Caumes E, Ehya N, Nguyen J, Bricaire F. Typhoid and paratyphoid fever: A 10-year retrospective study of 41 cases in a Parisian hospital. J Travel Med 2001; 8:293-297.

Greene MK, Kerr AM, Mclntosh IB, Prescott RJ. Acetazolamide in prevention of acute mountain sickness: A double-blind controlled crossover study. BMJ (Clinical research ed) 1981; 283:811-813.

166* Schlagenhauf P, Petersen E. Malaria chemoprophylaxis: Strategies for risk groups. Clin Microbiol Rev 2008; $21: 466-472$.

167 Oya A, Kurane I. Japanese encephalitis for a reference to international travelers. J Travel Med 2007; 14:259-268.

Cooke FJ, Day M, Wain J, et al. Cases of typhoid fever imported into England, Scotland and Wales (2000-2003). Trans R Soc Trop Med Hyg 2007; 101:398-404.

169 Steffen R, Connor BA. Vaccines in travel health: From risk assessment to priorities. J Travel Med 2005; 12:26-35. Pandey P, Shlim DR, Cave W, Springer MFB. Risk of possible exposure to rabies among tourists and foreign residents in Nepal. J Travel Med 2002; 9:127-131.

171 Mileno MD, Bia FJ. The compromised traveler. Infect Dis Clin North Am 1998; 12:369-412. Bradley DJ, Warhurst DC. Guidelines for the prevention of malaria in travellers from the United Kingdom. PHLS malaria reference laboratory, london school of hygiene and tropical medicine. Commun Dis Rep Review 1997; 7.

* 2 or more citations are tied for the same rank.

for an original research article published in 2013 by Bhatt et al which examined the global distribution and burden of dengue infection using cartographic modeling. The next most cited paper, published in 2006, had just over half as many citations (632) and reported the results from the GeoSentinel Surveillance Network of an analysis of 17353 ill returned travellers presenting to GeoSentinel sites around the world. Temporal analysis of the top 174 papers showed that the most productive decade for the most cited articles was 20002009, and 2006 was the year of publication with the greatest number (17) of top-cited papers. Figure 1 illustrates the total citation number per decade of publication in travel medicine, indicating that the current decade has witnessed the greatest level of citations to date. The most influential articles were published between 1952 and 2013. The oldest article was written by Dick et al and published in 1952 in Transactions of the Royal Society of Tropical Medicine and Hygiene; it described the isolation and serological diagnosis of the Zika virus. The most recently published papers to appear on the most cited list were published in 2013 by Leder et al in the Annals of Internal Medicine and Bhatt et al in Nature and described the findings of a GeoSentinel surveillance of 42173 ill returned travelers between 2007 and 2011 and the global distribution of dengue infection, respectively.

Table 2 lists the journals in which the greatest number of influential papers were published. The Journal of Travel Medicine published 41 of the top 174 most cited articles (23.4\%). The article with the highest number of citations (235) was published in the Journal of Travel Medicine by Hilton et al in 1997 at the Albert Einstein College of Medicine in New York City, USA. It reported the findings of a double-

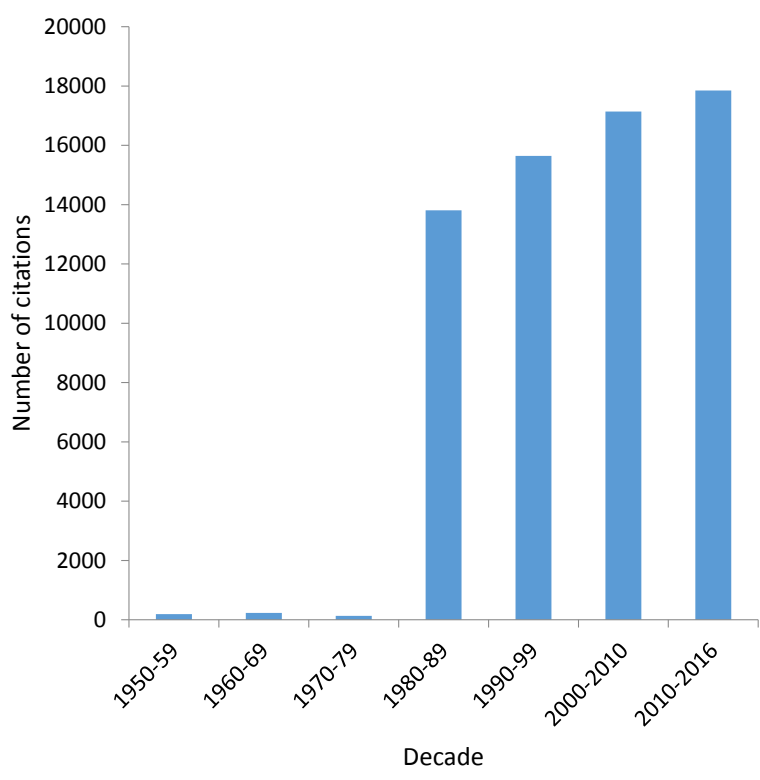

Figure 1. Temporal Trends in the Publication of Most Cited Articles.

blind randomized controlled clinical trial of 245 patients and concluded that the Lactobacillus GG species may be effective in preventing travelers' diarrhea. Of the 9 leading journals publishing 5 or more of the most cited papers, 2 were devoted exclusively or substantially to travel medicine, 2 to tropical medicine, 3 to general internal medicine and other specialties, 1 to infectious diseases, and 1 to sports and exercise medicine. The journal with the highest impact factor in the current analysis was the New England Journal of Medicine. 
Table 2. Impact Factor (IF) of Journals Publishing the Most Cited Travel Medicine Papers

\begin{tabular}{llcc}
\hline Rank & Journal & IF & Articles \\
\hline 1 & Journal of Travel Medicine & 1.880 & 41 \\
2 & American Journal of Tropical Medicine And Hygiene & 2.699 & 18 \\
3 & Clinical Infectious Diseases & 8.736 & 10 \\
4 & Lancet & 44.002 & 8 \\
5 & New England Journal of Medicine & 59.558 & 8 \\
6 & Travel Medicine and Infectious Disease & 2.192 & 6 \\
7 & Annals of Internal Medicine & 16.440 & 5 \\
8 & Medicine and Science in Sports and Exercise & 4.081 & 5 \\
9 & Transactions of the Royal Society of Tropical Medicine and Hygiene & 1.631 & 5 \\
\hline
\end{tabular}

Categorical analysis demonstrated that 122 of the 174 leading articles were original research articles, 47 were review articles, and 5 belonged to other article categories ( 1 letter to the editor on the H1N1 influenza virus, 2 conference papers, 1 short survey, and 1 editorial on logarithmic risk scales). Twenty-three papers were related largely to the basic sciences while 152 were principally of a clinical nature. The levels of evidence of the clinical articles mostly belonged to levels 2-5 of the Oxford Centre for Evidence-Based Medicine Levels of Evidence. Randomized controlled clinical trials comprised 5 of the most influential papers and investigated the efficacy of low molecular weight heparin for prevention of travel-related venous thrombosis, rifaximin for prevention of travelers' diarrhea, melatonin for alleviation of jet lag symptoms, acetazolamide for prevention of acute mountain sickness, and a virosomal malaria vaccine. Of the 47 review articles represented in the top 174 papers, 6 were systematic reviews and meta-analyses and addressed travelers' diarrhea (in 3 systematic reviews), hepatitis E, venous thromboembolism in air travel, and rapid diagnostic tests for malaria diagnosis.

By using citation counts as a proxy measure of researcher influence in the field of travel medicine, the top-ranked author was R. Steffen with 15 articles among the most cited (Table 3). The highest ranked author to appear on the list of most cited articles based on the cumulative citation count was J. S. Keystone with 1825 citations (Table 4). Fourteen authors, all highly active in travel medicine practice and research, had at least 5 articles in the top 174 most referenced papers. The United States had 85 of the most cited papers, followed by the United Kingdom with 40 and Switzerland with 32 . Sixteen countries produced at least 5 of the most cited

Table 3. Authors With Five or More Publications in the Top-Cited Articles

\begin{tabular}{lll}
\hline Rank & Author & Articles \\
\hline 1 & Steffen R. & 15 \\
2 & Schlagenhauf P. & 11 \\
3 & Von Sonnenburg F. & 11 \\
4 & Schwartz E. & 10 \\
5 & Keystone J.S. & 10 \\
6 & Castelli F. & 9 \\
7 & Caumes E. & 7 \\
8 & Freedman D.O. & 7 \\
9 & Loutan L. & 7 \\
10 & Weld L.H. & 7 \\
11 & Torresi J. & 6 \\
12 & Wilson M.E. & 6 \\
13 & Pandey P. & 5 \\
14 & Connor B.A. & 5 \\
\hline
\end{tabular}

publications, 10 of which were of European origin (Table 5). A total of 160 different institutions were represented in the analysis. The most prolific institution in the most cited article collection was the Ludwig-Maximilians-Universität based in Munich, Germany with 15 contributions (Table 6). Nine of the institutions with at least 5 articles among the top 174 papers were affiliated with European academic and clinical institutions. The Centers for Disease Control and Prevention in the United States was the source of 11 of the top-cited papers.

Table 7 presents a thematic analysis of the most cited publications in travel medicine. Nine broad themes characterized the group with at least 5 articles on the most cited publication list; air travel (29), malaria (26), post-travel assessment (16), travelers' diarrhea (14), and high altitude illness (13) were the most prominent subjects. Studies of the knowledge, attitudes, and practices of travelers comprised 6 of the most frequently cited papers. Three airport surveys conducted in 9 major European airports, 2 airports in Zimbabwe, and Johannesburg international airport received a combined total of 373 citations.

\section{Discussion}

Citation analysis is a widely endorsed measure of the influence of peer-reviewed articles published in medical literature. This method of evaluating the most influential output at a specialty level has been reported in other areas of medical practice, including pediatrics, ${ }^{11}$ orthopedic surgery, ${ }^{12}$ plastic surgery, ${ }^{5}$ and cardiac surgery. ${ }^{6}$ This study sought to identify the travel medicine publications that have exerted the greatest

Table 4. Authors With Largest Cumulative Citation Records in the TopCited Articles

\begin{tabular}{lll}
\hline Rank & Author & Citations \\
\hline 1 & Keystone J.S. & 1825 \\
2 & Von Sonnenburg F. & 1485 \\
3 & Steffen R. & 1261 \\
4 & Weld L.H. & 1196 \\
5 & Freedman D.O. & 1166 \\
6 & Pandey P. & 883 \\
7 & Schwartz E. & 826 \\
8 & Caumes E. & 781 \\
9 & Schlagenhauf P. & 779 \\
10 & Castelli F. & 768 \\
11 & Wilson M.E. & 583 \\
12 & Loutan L. & 502 \\
13 & Torresi J. & 425 \\
14 & Connor B.A. & 413 \\
\hline
\end{tabular}


Table 5. Countries of Origin of the Most Cited Articles

\begin{tabular}{|c|c|c|}
\hline Rank & Country & Articles \\
\hline 1 & United States & 85 \\
\hline 2 & United Kingdom & 40 \\
\hline 3 & Switzerland & 32 \\
\hline 4 & Germany & 21 \\
\hline 5 & Canada & 19 \\
\hline 6 & France & 18 \\
\hline 7 & Australia & 14 \\
\hline 8 & Italy & 12 \\
\hline 9 & Israel & 10 \\
\hline 10 & Spain & 9 \\
\hline 11 & Sweden & 8 \\
\hline 12 & Netherlands & 7 \\
\hline 13 & Nepal & 6 \\
\hline 14 & Singapore & 6 \\
\hline 15 & Belgium & 5 \\
\hline 16 & Denmark & 5 \\
\hline
\end{tabular}

Table 6. Institutions Publishing in the Most Cited Articles in Travel Medicine

\begin{tabular}{llc}
\hline Rank & Institution & Articles \\
\hline 1 & Ludwig-Maximilians-Universität München & 15 \\
\hline 2 & $\begin{array}{l}\text { Universität Zurich } \\
\text { Institüt für Sozial- und Praventivmedizin }\end{array}$ & 12 \\
\hline 5 & $\begin{array}{l}\text { Centers for Disease Control and Prevention } \\
5\end{array}$ & 11 \\
\hline 6 & $\begin{array}{l}\text { Universita degli Studi di Brescia } \\
\text { Toronto General Hospital }\end{array}$ & 10 \\
\hline 8 & $\begin{array}{l}\text { University College London } \\
\text { Hôpital Pitie Salpetrière }\end{array}$ & 8 \\
\hline 11 & $\begin{array}{l}\text { University of Toronto } \\
\text { Rnal Melbourne Hospital }\end{array}$ & 7 \\
\hline 13 & $\begin{array}{l}\text { Emory University } \\
\text { Hôpitaux Universitaires de Genève } \\
\text { University of Washington Seattle } \\
\text { Hospital Ramon y Cajal } \\
\text { University of Melbourne } \\
\text { London School of Hygiene and Tropical Medicine }\end{array}$ & 6 \\
\hline
\end{tabular}

Table 7. Thematic Analysis of Most Frequently Cited Articles

\begin{tabular}{llc}
\hline Rank & Subject & Articles \\
\hline 1 & Air travel & 29 \\
2 & Malaria & 26 \\
3 & Post-travel assessment & 16 \\
4 & Traveller's diarrhoea & 14 \\
5 & Altitude illness & 13 \\
6 & Diseases associated with vectors & 8 \\
7 & Jet lag & 8 \\
8 & KAP of travellers & 6 \\
9 & Epidemiology & 5 \\
\hline
\end{tabular}

academic influence on the discipline by ranking its most cited works. Bibliometric advice established that 50 citations would be a reasonable, though arbitrary, benchmark of influence for travel medicine, given that the first specialized travel medicine journal only came into being 22 years ago. Since then, travel medicine has come of age and its research output has expanded greatly. Faculty of Travel Medicine recommendations for the practice of travel medicine ${ }^{13}$ and an extensive body of knowledge ${ }^{14}$ guiding continuing medical education in the field have been published. While the Zika virus infection has been the subject of a recent bibliometric analysis, ${ }^{15}$ this is the first overall citation analysis regarding travel medicine.

Citation analysis has limitations in evaluating the academic importance of an article. ${ }^{16}$ There is a temporal lag between publication and citation, with the most recent article being at a disadvantage in this regard. However, it is believed that citation analysis should be performed at reasonable intervals, e.g., 5 years, to provide the most up-to-date view of publication trends. Self-cited articles were not excluded, and citations in textbooks or conference proceedings were not considered to avoid possibly introducing selection bias into the methodology. The recognized tendency for authors to preferentially cite articles in their target journal may also potentially inflate citation numbers for some papers, although the rigor of the external peer review process and editorial oversight exercised by the high quality academic journals featured in this study's citation table provide reassurance about the accuracy of the citation report. A further source of bias in relation to citations in general is the so-called snowball effect' which means that authors are more likely to cite a work because it has been cited in previous publications rather than purely for its scientific content and academic quality. Furthermore, there is an obvious bias toward articles published in English, but the leading journals in the field and in related specialties are all English language publications. Citation analysis also ignores whether a citation is positive or negative. It is widely accepted that, with the passage of time, truly 'classic' papers are gradually cited with less frequency, because they have been consumed by current knowledge in a process of "obliteration by incorporation." ${ }^{17}$ The researchers acknowledge that the detailed bibliometric analysis in this study may have excluded a small number of relevant papers which had been incorrectly indexed or the keywords of which were not comprehensive. Since travel medicine has a far reach and overlaps other disciplines, an even wider search strategy may have disclosed additional highly cited articles. This limitation is inherent in every citation analysis.

This is the first citation analysis to be conducted in travel medicine, and it highlights the most influential topics in the field. Air travel-related publications featured most prominently among the most cited papers, followed closely by malaria. Both topics affect a large number of international travelers and are fertile fields of research activity. This finding aligns closely with the observation that air travel-related venous thrombosis, jet lag, and prevention and treatment of travelers' diarrhea were among the topics represented by the highest level of scientific evidence in the form of systematic reviews and randomized controlled clinical trials. Analysis of the time course of travel medicine articles with the greatest 
academic impact identified the decade 2000-2009 as the most prolific decade in travel medicine research to date. It is likely that, as travel medicine research output increases over time, the decade of greatest influence will shift to a later time period, making follow-up citation analyses essential. The ease of modern online literature database searches and the migration to a web-based continuous publication platform for leading journals have removed barriers to accessing the most recently published articles in medical literature, a factor which may diminish this long observed time lag in citation metrics.

While the majority of classic travel medicine papers were published in specialized travel medicine and tropical medicine journals, a reasonable proportion of the most cited articles appeared in high impact factor general internal medicine and infectious disease journals. Travel medicine interdigitates with a large number of other specialties, including general practice, internal medicine, public health medicine, infectious diseases, and occupational medicine. While this citation analysis did not specifically examine the citing journals, it does suggest that the discipline of travel medicine is exerting a wide sphere of influence across clinical practice. The high proportion of review articles among the most cited papers is reassuring as it demonstrates the maturity of travel medicine as a field of academic enquiry. These review articles were mostly narrative literature reviews rather than systematic reviews; however, the latter represents a higher form of scientific evidence that takes account of bias in research. That an editorial appeared in the top 174 papers speaks to the capacity of well-written editorial articles to influence academic research.

The geographic distribution of classic papers in travel medicine was weighted towards the United States, United Kingdom, Switzerland, and Germany, where many of the leading institutions and most prolific researchers were also located. Only two Asian countries and not a single Latin American or African country were found in the most cited article list. There may be a less skewed distribution of publications in future citation analyses of travel medicine as regional travel medicine societies such as the Asia Pacific Travel Health Society, ${ }^{18}$ South African Society of Travel Medicine, and Latin American Society of Travel Medicine ${ }^{19}$ raise the profile of travel medicine research among their members and as research funding becomes available to support such activity.

\section{Conclusion}

Using citation analysis as a proxy marker of influence in academic travel medicine, this study offers a perspective on the key publications in this relatively young area of practice. Despite its limitations, citation analysis highlights the countries and institutions of origin of the most seminal travel medicine research output. Furthermore, it provides insights into the direction in which travel medicine has progressed since its origins some 40 years ago. A follow-up bibliometric analysis of travel medicine literature will focus on identifying areas of unmet research need within the field and will confirm future research priorities.

\section{Authors' Contributions}

Both authors contributed equally to the conception, design,
Research Highlights

\section{What Is Already Known?}

Travel medicine has flourished since its origins in the early 1980s into a multidisciplinary discipline which serves the health needs of international travelers. No comprehensive citation analysis of travel medicine-related articles has been published to date.

\section{What This Study Adds?}

A total of 174 travel medicine-related articles with at least 50 citations each was found. The most productive decade for these most cited articles was 2000-2010. One hundred twenty-two of the articles were original research articles, and 47 were review articles. The top-ranked author published 15 articles among the most cited. Nine broad themes emerged from the most cited article list, including air travel, malaria, post-travel assessment, travelers' diarrhea, and high altitude illness.

execution, drafting, and review of this manuscript. The final draft was read and approved by both authors.

\section{Conflict of Interest Disclosures}

Professor Gerard Flaherty serves as Associate Editor for the Journal of Travel Medicine and on the editorial board of Travel Medicine and Infectious Disease.

\section{Ethical Approval}

Ethics committee approval was not required for this study.

\section{Funding/Support}

None received.

\section{Acknowledgments}

The authors wish to acknowledge the helpful advice received from Ms. Rosie Dunne, bibliometrician at the Hardiman Library, National University of Ireland, Galway.

\section{References}

1. Piyaphanee W, Chanthavanich P. Residency training in travel medicine - a 3-year journey to become a specialist. J Travel Med. 2016;23(5). pii: taw041. doi:10.1093/jtm/taw041.

2. Flaherty G, Thong Zi Yi C, Browne R. The missing link: introducing travel medicine into the undergraduate medical curriculum. J Travel Med. 2016;23(5). pii: taw038. doi:10.1093/jtm/taw038.

3. Talbot EA, Chen LH, Sanford C, et al. Travel medicine research priorities: establishing an evidence base. J Travel Med. 2010;17(6):410-415. doi:10.1111/j.1708-8305.2010.00466.x.

4. Eyre-Walker A, Stoletzki N. The assessment of science: the relative merits of post-publication review, the impact factor, and the number of citations. PLoS Biol. 2013;11(10):e1001675. doi:10.1371/journal.pbio.1001675.

5. Joyce KM, Joyce CW, Kelly JC, et al. Levels of evidence in the plastic surgery literature: a citation analysis of the top 50 'Classic' papers. Arch Plast Surg. 2015;42(4):411-418. doi:10.5999/ aps.2015.42.4.411.

6. O'Sullivan KE, Kelly JC, Hurley JP. The 100 most cited publications in cardiac surgery: a bibliometric analysis. Ir J Med Sci. 2015;184(1):91-99. doi:10.1007/s11845-014-1193-1.

7. Tsai YL, Lee CC, Chen SC, et al. Top-cited articles in emergency medicine. Am J Emerg Med. 2006;24(6):647-654.

8. Adams AB, Simonson D. Publication, citations, and impact factors of leading investigators in critical care medicine. Respir Care. 
2004;49(3):276-281.

9. Scopus database. https://www.scopus.com/. Accessed 5 September $5,2016$.

10. Oxford Centre for Evidence-Based Medicine. 2011 levels of evidence. http://www.cebm.net/wp-content/uploads/2014/06/ CEBM-Levels-of-Evidence-2.1.pdf. Accessed September 5, 2016.

11. Quinn N, Hensey O, McDowell DT. A historical perspective of pediatric publications: a bibliometric analysis. Pediatrics. 2013;132(3):406-412. doi:10.1542/peds.2013-0283.

12. Lefaivre KA, Shadgan B, O'Brien PJ. 100 most cited articles in orthopaedic surgery. Clin Orthop Relat Res. 2011;469(5):14871497. doi:10.1007/s11999-010-1604-1.

13. Chiodini JH, Anderson E, Driver C, et al. Recommendations for the practice of travel medicine. Travel Med Infect Dis. 2012;10(3):10928. doi:10.1016/j.tmaid.2012.05.002.

14. Kozarsky P. The Body of Knowledge for the practice of travel medicine - 2006. J Travel Med. 2006;13(5):251-254.
15. Martinez-Pulgarin DF, Acevedo-Mendoza WF, Cardona-Ospina JA, et al. A bibliometric analysis of global Zika research. Travel Med Infect Dis. 2016;14(1):55-7. doi:10.1016/j.tmaid.2015.07.005.

16. Callaham M, Wears RL, Weber E. Journal prestige, publication bias, and other characteristics associated with citation of published studies in peer-reviewed journals. JAMA. 2002;287(21):28472850.

17. Chuang KY, Ho YS. A bibliometric analysis on top-cited articles in pain research. Pain Med. 2014;15:732-744.

18. Piyaphanee W, Steffen R, Shlim DR, et al. Travel medicine for Asian travelers - do we need new approaches? J Travel Med. 2012;19(6):335-337. doi:10.1111/j.1708-8305.2012.00661.x.

19. Rodriguez-Morales AJ, Palacios $\mathrm{H}$. Trends in the publication of scientific research in travel medicine from Latin America. Travel Med Infect Dis. 2009;7(5):323-324. doi:10.1016/j. tmaid.2009.06.005. 